\title{
タンズィマート改革期におけるトルコ農村社会
}

一土地法改正之行政・税制改革一

\section{Turkish Rural Society during the Tanzimat Period}

Local Administrative and Tax Reforms

in relation to the Land Law Revisions-

\section{江川ひかり \\ EGAWA Hikari}

\begin{abstract}
In the present paper, the author analyzes the local administrative and tax reforms during the Tanzimat period (18391876) in relation to the Land Law Revisions, in order to understand the problems posed for Turkish rural society at the time. In the present paper, the Land Law Revisions means the 1858 Land Law and the process of codifications and revisions.
\end{abstract}

The aim of the Tanzimat reform movement of the Ottoman Empire was to establish a "modern" state based on the rule of law. Prior to the reform movement, Turkish rural society can be characterized as existing in a state of weakening central control and controlled by local notables ( $\hat{a}^{\prime} y \hat{a} n s$ ) acquiring de facto private ownership of land through tax farming contracts and the management of large scale farms known as ciftliks. Thus the local notables gained control over local political affairs. Therefore, the objective of the Tanzimat reforms was to regain state control over rural society by rebuilding a centralized state order.

Research concerning the administrative and tax reforms during the Tanzimat period has been dominated by institutional historical approaches, while the perspective of the land problem in relation to the agrarian society has been virtually ignored. On the other hand, studies concerning the Land Law Revisions from the perspective of

* 財団法人東洋文庫奨励研究員

Fellowship Researcher, The Toyo Bunko (Oriental Library) 
legal history have been conducted by Ö. L. Barkan and H. Cin. The only research to date concerning the direct effects of the Tanzimat reforms on agrarian society has been conducted by $H$. Inalc1k, who dealt primarily with the early period of the Tanzimat reforms, and thus provides minimal or no analysis of the actual influences of the post-1850 reforms and the Land Law Revisions on the rural society.

Concerning the process of implementation of the Land Law Revisions, Y. Nagata has stressed the necessity of analyzing the political and socio-economic struggles over landownership among the central government, local notables and rural population in relation to the Ottoman Empire opening up to the penetration of the international economy. Thus with consideration to the above mentioned factors, the author focuses, in the present paper, on the interests and roles played by the above three parties in a discussion of the concrete points of dispute: namely, the strengthening of control over state land (mîrî), and a policy to standardize the $\hat{a s s a ̂ r}$ tithe and later temporarily increase the rate.

From this perspective, the author is able to show that these two attempts are very closely related not only to the Land Law Revisions, but also to the Tanzimat administrative and tax reforms. In concrete terms, firstly, the government, in order to regain control of rural society and rebuild a centralized state organization, aimed at streng. thening its control over mîr through the regional administrative mechanism. In the Title deed Act of 1859, we find detailed terms concerning the registration of land titles, which clealy illustrates an attempt to legitimize the holdings and the use of mîr.

Secondly, the author demonstrates that the Tanzimat tax reforms were implemented with the express purpose of guaranteeing land tax revenues as the largest source of funding for the entire reform process. After abolishing most of the traditional taxes, the government standardized the âşâr tithe at a rate of $10 \%$ for the whole country. Furthermore in 1867, in return for recognizing an enlarged inheritance rights of personal holding of the $m \hat{\imath} r \hat{\imath}$, the government temporarily attempted to increase the $\hat{a} s ̧ a ̂ r$ tithe. in other words, the firm establishment of both centralized control over $m \hat{\imath} r \hat{\imath}$ in rural so- 
ciety and the $\hat{a} s ̧ \hat{a} r$ tithe as an important source of revenue for impoverished public coffers were legally determined within the process of implementing the Land Law Revisions. Furthermore, tax exemption on the cultivation of marketed produce and permission of landholding by foreigners depicts the international situation in which the Ottoman Empire was placed and moreover reflects the Land Law Revisions.

\section{I. 問題の所在}

オスマン帝国のタンズィマート改革 (1839-1876) は，法治主義に基づく「近 代的」国家体制の確立を目指す諸改革である。

タンズィマート改革以前の地方社会においては，中央集権支配の弱体化とと もに, 地方名士アーヤーンが徵税請負権の取得, あるいはチフトリキとよばれ る農場経営を基盤に，事実上の私的土地所有を行い，地方政治の実権を手にし ていた。とのため，徵税請負権，チフトリキ経営などに基づくアーヤーンに関 する問題は，今日のオスマン帝国社会経済史研究に打ける中心的テーマ(1) で，中でもとりわけ土地所有問題が焦点となっていることは疑いない。

このような背景から，タンズィマート改革の最大の意図は，地方社会を国家 が再び掌握し，中央集権的国家体制を建て直すことにあった。すず，改革に必 要な資金の最大の収入源である土地からの税収を確保するための税制改革，土 地管理をつかさどる地方行政改革が括こなわれた。さらに，国家的土地所有原 則を再確認し，所有権が国家に帰属することを明確にうたった1858年土地法が 発布された。58年土地法編纂委員たちは，ティマール制の廃止（1831年）と， スレイマン時代から大きく変化した土地所有をめぐる諸状況とに照らして, 従 来の土地法令の改訂と補足が時代の要請となったと述べている。従って58年土 地法発布の目的の一つは，ティマール制下でスィパーヒーが合法的に，あるい はアーヤーンや徵税請負人などが非合法的に掌握してきた土地証文授与権を， 一元的に国家の手に取り戻すことだった。

しかし，これらの諸改革と土地法改正とは，従来の既得権益を劦かされたこ とに対するアーヤーンの抵抗と, 生活が改善されると思った地方住民の期待と, 国家の意図する改革を実行し得る官吏の不足といら状況下で，様々な問題を生 みだした。そのため中央政府は，一方的に中央集権的改革を推し進めるだけで はなく，地方名士の要求と，地方住民からの不満とを考慮し，同時に，西欧列 
強による圧力にも答えなければならなかった。このような国内，国際環境の中 で行なわれた諸改革の過程に，伝統から「近代」への移行にともなら混乱の様 子を窥うことができる。以上のような歴史的背景を念頭に入れつつ，本稿では タンズィマート諸改革の中で, とりわけ農村社会や土地問題に大きく影響を与 光た地方行政改革和よび税制改革の実際と土地法改正との関連性を整理し，そ こにひそも問題点を検証したい。

\section{II. 研 究 史} 集』は制度史中心で, それらのいくつかは E. エンゲルハルトの見解を繰り返

タンズィマート諸改革に関する基礎的研究書『タンズィマート百周年記念論 すだけとの批判もなされたが，タンズィマート研究の出発点となった。その後， 制度史中心の概説から前進し, 近年個別研究が蓄積されつつある。例えば, 地 方行政改革に関しては， I.オルタイルやM.チャドゥルジュによって研究がな されているが，都市の行政や社会・経済問題が中心で，農村社会そのものと地 方行政改革との係わりに重点が敊かれているわけではない。税制改革に関する (11) 研究からは統計的数字を利用できるが，社会的背景の分析は欠落している。

筆者は現在, 58年土地法の編纂・改正過程を当時の国内外の政治, 経済, 社 会環境をふまえて考察することに取り組んでいるが，この土地法改正に関する 研究は Ö.L.バルカシややH. ジンによって法制史的観点からは研究がなされて きた。

従来の法制史的観点からの研究を批判したH. イナルジクは，税制・行政改 革や土地所有の問題点を指摘し, 諸改革の過程で従来の特権を奪われた地主た ちが，伝統的税制と新たな改革との矛盾によって発生した混乱の中で不満をつ のらせた農民を扇動し，反乱を起こすに至った過程をバルカンの農民反乱の事 例から考察した。従って, 本稿に一番近い研究, すなわらタンズィマート改革 が当時のオスマン地方社会に和よぼした影響を直接考察の対象にしたのはイナ ルジクだけとい方る。イナルジクはこれらの研究を通して, 農村社会に蛙ける 土地問題がバルカン民族独立運動へと発展していく原因の一つであることを明 らかにした。とはい光，イナルジクが扱った事例がタンズィマート改革期前期 であるため，50年代以降の諸改革预よび土地法改正が農村社会へ及法した影響 に関する具体的分析はまだ手つかずの状態とい觉る。加兄て，前述したとおり 
アーヤーンを中心とする社会経済史研究は主として19世紀初頭までを扱ってい (16)

るにすぎない。

D. カータルトは，19世紀初頭から後半をで中央政府と地方名士との間には， 徵税請負をめぐる絶觉間ない協力と摩擦とが並存しながらも, 両者は同盟関係 を存続させたため，農民は確実に納税すべき状況にあったことを指摘する。一 方，永田は，土地法改正の地方社会に打けるその現実的プロセスについては， 土地所有をめぐる中央政府，地方名士，地方住民の三者の政治的・社会経済的 抗争が世界経済の浸透と共に研究されなければならないと主張している。そこ で，筆者は中央政府，地方名士，地方住民の三者の思惑に着目しつつ，本稿で は特に具体的焦点となる国有地管理の強化と, アーシャール税の一元化拈よび 增税策について論ずる。

\section{III. 国有地管理の強化}

1839年11月，ギュルハネ勅令発布によって開始されたタンズィマート改革に 执いては，まず財政的基盤となる税収入の確定が中央政府の早急な課題となっ た。そのためには農村社会に拈ける国有地の登録が租税徵収の基礎となったこ とはいうまでもない。このような国家による国有地管理は地方行政機構を通じ て行なわれた。

ティマール制下でスィパーヒーのみに与えていた土地証文授与権は，ティマ ール制が形骸化するとともに改税請負人や地方名士によって非合法的に授与さ れていたといわれている。実際, 高等司法審議会議および高等総会議 (Meclis -i Âlî-i Umûmî) は1847年, 土地証文が請負人の名義に登録されるという無 秩序な状態を改め，今後は土地証文がすべて財務局から授与され，証書は印刷 された用紙で，財務局長の印で押印されていなければならないと定めた。こう した文言からも，土地証文の発行和よび授与をめぐる従来の不正や混乱を正す ため，政府はタンズィマート改革の初期から国家による国有地管理を漸次試み ていることが理解される。

以上のような過程を経て，58年土地法第 3 条では，先にふれたよらなティマ ールやゼアメトの保有者とともに，アーヤーンなどの徵税請負人や国有地の䘗 税官によって国有地が処分されてきた事実を指摘し, 今後は担当官の許可によ って処分されると規定された。このことは，地方名士や徴税請負人などによっ 
て土地証文が授与されてきた非合法性を中央政府も良く認識していることを示 して和り，それを正とうとしていることがわかる。

実際58年土地法発布に際し, タンズィマート委員会公文畫には, 58年土地法 の写し 7,500 部が用意され, これらの写しはイスタンブルの必要な地区と, 各 州議会, 県議会, 郡議会, 法廷, ムフティたちへ配付され, 残部は希望者へ国 家から売られると記されている。さらに，58年土地法の基本原則をらけて，こ れを実行するための細則である土地証文法令が59年に発布された。この法令は 国有地に持ける保有権の登録，財務官吏の権限，土地証文の移転手続きなどを 規定したもので，地方行政機構を通した国有地の管理強化を徹底させる意図を 含んでいるといえる。

59 年土地証文法令の内容を具体的に説明すると，まず第 1 に，土地証文には 評価額, 所在地区和よび郡の名，境界，面積が記載され財務局の特別な印で押 印され，用紙の上部にはスルタンの花押が印刷されると規定された。そして以 上の内容が，郡ごとの土地台帳（arâzî defteri）に記され，譲渡，相続，競売 の際にも，記録がなされ，それらの土地台帳は県行政府に抢いて保管されるこ とが定められた。

第 2 に，58年に発布された土地法の実施には，州県レベルでは州知事，県知 事, 財務官吏 (mal me'murlar1), つまり中央から派遣された国家官吏があ たり，郡レベルでは，郡の地方名士の中から選ばれ，財務・行政・警察すべて の権限を掌握していた郡長が担当していた。これらの官吏は, 具体的には荒黄 地の合法的開墾, 放置され無主地となった土地，すなわち土地証文の請求対象 となった土地の再開発，国有林あるいは村落共同利用地の個人保有の防止など を監督した。

第 3 亿，国有地に特ける保有権の移転に際しては，州打よび県では中央から 派遣された財務官吏のみがこれにあたり，郡では郡長があたった。例えば，土 地保有者が無償相続人を残さず死亡した場合，無主状態になった土地は土地証 文代金の支払で，土地証文権取得資格者すなわち有償相続人に移転されること がすでに58年土地法で規定されていた。59年法令では，土地保有者が無償相続 人を残さず死亡し，有償相続人が存在する場合，土地の面積が 100 ドニュム （約 10 ha）以下なら郡議会で, 100 ドニュムより上の場合, 県議会で判断し, 有償相続されだた 
C.イサウイ゚によれば，当時の平均的農民のもつ土地面積はアナトリア東部 やバルカン地域を除けば平均約 1〜10ha であったことから，一般農民の相続， 譲渡等の手続きは郡レベルで完結していたと考兄られる。

これら 3 点から，58年土地法预よび59年土地証文法令が正しく笑行されるか 否かは，州知事，県知事，財務官吏，つまり中央から派遣された国家官吏特よ び，地方で選出される郡長の手腕にかかっていたが，郡長職は実は旧来の名士 がこれを独占していたことは，前述したイナルジクの研究によっても明らかに されている。つまりこの時点では，中央政府は，地方社会を直接把握したいと 思いながらも財政的理由と改革を実行できる国家官吏の不足とによって，ある いは地方名士の影響力を考慮して，郡レベルまではまだ官吏を派遣できず，従 って中央政府は改革の意図を貫徹できなかった。機構上，郡長が中央と直結す るのは，地方行政改革の集大成といえる1864年地方州法発布以後のことである。

以上述べてさた国有地管理の実際を明らかにするため，筆者は各県ごとに保 管された土地台帳と，実際に土地保有者へ授与された土地証文とを比較・対照 しようと試みたが，アンカラの地券地籍簿総局所蔵の土地台帳は，今日にいた ってもな和，土地の係争が継続されているため，個人のプライバシーにかかわ る文書としてトルコ人，外国人いずれにも公開が禁止されていることを知らさ れた。

その後筆者は幸運にも，寺島憲治氏の個人的㲈がりから，ブルガリアのロー ヴェッチ州ビャーラ・チェルクヴァ町に住さA氏所蔵土地証文（以下「A氏文 書」といら）を見せていただく機会を得た。1805/06 年から1875年までに発行 された12点の「A氏文書」と，58年土地法および59年土地証文法令の規定とを 対照すると, 以下のような点が指摘され得る。

第 1 に，土地証文の用紙は， 1 番（1805/06年）から 9 番（1865/66年）まで がスルタンの花押なしの無地紙で，10番（1875年）から12番（1875年）のみ花 押が印刷されている。つまり，1847年土地証文法令でうたわれた花押付土地証 文が「A氏文書」に現われるのは28年後といらことになる。

第 2 に，土地証文の記載内容は 1 番から12番までほぼ類似している。すなわ ら，取引対象となる土地の種類，四方の境界，面積，前保有者名（「売り手」）, 新保有者名(「買い手』), 売値が記され, 国有地とみなされた耕作地に打ける 保有権の移転には「売却 (fürûht)」といら法律用語が使われている。そして， 
新保有者の土地占有を正当化するために土地証文が授与され，土地証文税の支 払いが義務ら゙けられている。この記載内容は，59年土地証文法令の規定に合致 するもので, 同法令は従来の土地証文の内容を「近代的」に形式化することを 狙っていたと考光られる。

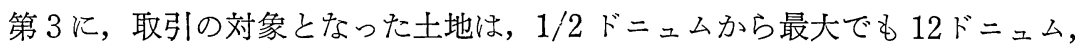
平均 4.6 ドニュA（約 $46 \mathrm{a} ）$ であり, 従って郡レベルで移転手続きが十分可能 な小地片であることがわかる。ただし，「A氏文書」が州属する村は，X・べ イのワクフ村で, 保有権の移転を許可する官吏の役割をここではミュテヴェッ リが果たしている。つまりこの村では, ムテヴェッリが19世紀初頭からタンズ ィマート改革期を通じて変わることなく土地証文授与権を所有していたことが 明らかになった。

以上の具体例から，中央政府が地方行政を通じて国有地管理の強化を早急に 行な称らとしていたにるかかわらず，国有地管理を実際に行ら郡の地方行政レ ベルでは, タンズィマート改革後期に叔いても中央の政策がなかなか実行にら つされなかったことが䆹光る。つまり，農村社会は事実上地方名士の手中にあ ったことは制度上からも，前述したイナルジクの諸研究からみても想像に難く (37) ない。

ただし，中央政府は現状に対して全く野放しだったわけではなく，地方名士 の代表をイスタンブルに召集して地方の現状や改革に対する意見を聴取する一 方で, 視察官を地方に派遣することによって現地の実態を調查し地方住民の声 を聴く努力をして，その都度地方の諸問題に対処した。従って地方行政改革の 過程は, 混乱はありながらも中央政府の権力が徐々に郡レベルへと浸透し, そ れが地方社会に括ける地方名士の弱体化を狙っていたと推察される。

他方，中央政府は1867年，外国人に対して私有不動産処分を認可する。1 1850 年代，オスマン臣民の名義のるとに土地を購入する外国人がいたが，彼らによ る自国式の農業経営は失敗しだていら。だが，1867年法令導入後の68年にはイ ズミル近郊で農業に適した土地の最低 $1 / 3$ がイギリス人の土地証文権付財産に なったとの.クルムジュは述べている。このように土地証文は，オスマン臣民 のみならず，外国人に対しても土地を保有する正当性の証となったのである。 


\section{IV. アーシャール (ÂÂâr) 税の一元化亡増税策}

税制改革の基本は，徵税機構の中央集権化，免税特権の廃止と支払い能力に 応じた税の徵収, 税目の簡略化の 3 点が挙げられる。

1840年公文書では, 中央が徵祝官を任命することに基づき徵税請負人の租税 徵収権は以後認められないこと,ティマール制下で授与された免税特権は廃止 され，これらの特権享受者汶対しても一律，平等淉税されること，地方によ って異なる種々の伝統的諸税が廃止西るいは簡略化されることなぞが明確に規 定されだた

税目の簡略化汇関しては，従来農民に課せられてきた耕作税，急農税，綿花 税などの諸税が廃止されて，基本的に収穫物に対しては一律 $1 / 10$ を課すアーシ ヤール税として一元化された。ささらに, 従来戦争時などに課せられた特別税 (avâr1z)，市場で徵収された計量税 (ihtisâb resmi), 強制労働 (angarya)

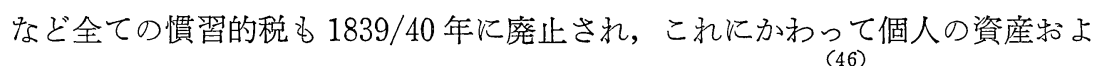
び収入に対して平等に課せら和る資産税（temettü“vergisi）に統一された。 この資産税算出のため，1844/45 年にかけて，個人資産に関する調查が一部の 地域で行われ, 今日「資産台帳 (Temettü‘ât Defterleri)」としてイスタン ブル総理府古文書局使っている。この「資産台帳」には家屋，耕作地，ぶぞ ら烟など個人の財産，そこから得られる収入拉よび税額が記載されており，こ のような調査にも地方住民の資産を詳細他把握しょうとする中央政府の意図が 見いだされる。ただし，この「資産台帳」に基づいて商工業者核説された資 産税は例外を除き外国人には第一次世界大戦時まで免税だったた。

さて，農村社会に関連する税目の中でもっとも重要なるのはいらまでもなく アーシャール税である。アーシャール税とはシャリーアで定められた収穫物に 対する税で, 文字ど扣りば十分の一税を意味している。ただし, アラブ地域で

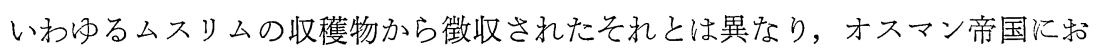
いては国有地（arâzîi-i mîrîye）の収穫物飞課税された税で，ハラージュ・ム カッセメに相当するるのと考兄られてきた。 $15 \cdot 16$ 世紀以来, 地方によって $1 / 10$ から $1 / 2$ までの幅が異なる税率は, 各地域ごとに作成された検地帳渴載 された法令で規定されていた。

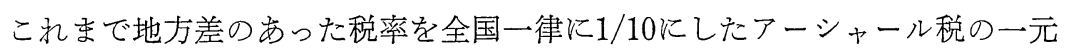
化は，一方では伝統的諸税の廃止とい光るが，他方では生産力の異なる土地か 
らの収穫物に同率で課税する不公平さを招き，また国家にとっては税収入減少 への道を開くことになった。タンズィマート改革によって始まった徴税官によ る税の徴収は，実際には徴税業務に不慣れであったり，官僚としての自覚の希 薄さから，また一方ではアーシャール税の一元化による混乱が原因となって徴 税率が低下し，アーシャール税の徵収は1842年, 再び徵税請負へだされること になった。

次に，アーシャール税の一元化が58年土地法ではどのように規定されたのか を整理してみたい。アーシャール税は，国有地，つまり土地証文によって保有 される土地の収穫物に課税された。具体的には耕作地（tarla）, 採草地（çay1r）はもとより，土地証文によって保有される夏営地（yaylak），冬営地（k1şlak）も国有地とみなされたため，耕作地に準じて課税された。すなわち「地 味に応じた税が課せられる (第 24 条)」と規定された夏営地税, 冬営地税も， アーシャール税に組み达まれた。

さらに，国有地として土地証文によって保有される土地上に建設された建物， あるいは樹木に対して, その借地料として課せられたウシュル税相当の土地顀 貸料 (icâre-i zemin, mukâta'a-i zemin) も, アーシャール税の一種と考兄 られる。

他方，商品作物に対するアーシャール税には特別措置がとられた。58年土地 法和よび59年土地証文法令では，荒れ地を新たに開墾して耕作地にした場合， 土地証文代金は請求されず，用紙代のみが徵収され，土地証文が授与された。 そしてこのような土地からは一年間, アーシャール税が免除されると定められ た。この時点では特に作物について限定されてはいないが，商品作物栽培を奨 励した政府は 1862 年，新たに開辗した土地に綿花を作付する場合， 5 年間の， 63年には新たにオリーブを作付けする場合， 3 年間のアーシャール税を免除し (54)

ている。綿花やオリーブ栽培がイズミルを中心とする地域に招いて，外国人に よって大規模に展開されたことを考慮するならば，このような免税措置は国内 の新興農民のみならず，外国人に有利に働いたことは間違いなく，加えて外国 人による土地証文付耕作地の保有を容易にさせ，さらには67年の外国人私有不 動産処分の認可を導くことになったとも考兄られる。

次に，相続権桩大に伴らアーシャール税の臨時徵収について述べたい。

土地法改正過程に括ける相続権の拡大は, 法的観点からみるならば，保有権 
の処分制限の緩和であり，私的所有権への移行とみなすことができる。この点 について，カータルトは，国有地に拈ける相続権の拡大が私有財産に和けると れに法制史上類似している点が従来誇張されてきたことを批判し，むしろ相続 権に関する諸規則の多くは土地の保有および耕作の継続を主眼としていた点が 強調されるべきだと指摘している。筆者は，この指摘を具体的に裏付けるもの こそが，相続権の拡大にともなら増税策であると考えている。58年土地法では， 国有地は息子と娘，父母へ無償で相続されると規定されたが，67年の法令では 息子と娘，孫，父母，異母兄弟姉妹，異父兄弟姉妹，夫と妻にまで無償相続権 が拡大された。同時に，この相続権拡大に伴い，アーシャール税の臨時徵収が スルタンの䡃令によって決定されたのである。

スルタンへの上奏文によれば，相続権の拡大は,「農民の利益保護」と「農家 の崩壊防止」のために, 同時に国有地の保有者の死亡に際して無主地の耕作地 がそのまま外部の者の手に渡ることを防止する目的で提案されたことがわかる。 同時に，上奏文には帝国の富の基本は農民であり，このため国家は農家の権利 と利益とを考慮する義務があるとも述べられている。さらに相続権の拡大は土 地保有者への権利の拡大とみなされるため，新たな権利付与の代償として，ま た歳入損失を補らものとして，通常のアーシャール税に加えて収穫物の $15 \%$ の 付加税を $1867 / 68$ 年から 5 年分割で国庫へ支払らことがスルタンの勅令によっ て定められた。

スルタンの勅令で見逃せない点は，スルタンによって「私有認可証」を与え られた私有地も，アーシャール税の対象となったことである。勅令では詳細は 述べられていないが，「私有認可証」を付与された私有地は，58年土地法では 国有地とはみなされなかったが，ここに至り国有地に準ずる扱いを受けるよら になったことは，財政の窮乏が私有地への課税措置となって現われたことを意 味している。同時に，私有地への課税措置と国有地に拉ける保有権拡大とは， 私有地に拉子る所有権と，国有地に拈ける保有権が接近しつつあることを意味 しているといえる。

アーシャール税が総歳入に占める割合は，1858年の約 $31 \%$ に対し，1875/76 年には約 $41 \%$ と $10 \%$ も増加している。A. シェネルはこの理由を農業生産の増 加と輸送手段の発展とに求めているが, 筆者は相続権拡大に伴らアーシャール 税の増税策こそが増加の大きな要因と考えている。すなわち，中央政府が耕作 
地に怙ける農民の権利拡大を保障し，その代償としてアーシャール税を課した ことは，中央政府による税制改革と土地法改正とが密接に連関していたことを 示す好例であるといえる。

アーシャール税の他に土地に係わる税としては, 土地証文税, 新たに土地証 文授与に伴ら用紙代, 相続税, 譲渡税などが挙げられる。その他, 羊税や非么 スリムに対する人頭税（後の兵役免除税）などの諸税も，農民にとって大きな 負担となったことはいらまでもない。アーシャール税，羊税，土地証文税のみ を考党ても，1870年代はじめには総税収入の 2 分の 1 をこえ, その後も増加し ていく。加えてその他の諸税を考慮するならば，タンズィマート改革期の国家 財政は農村社会に大きく依存して和り，膨れかがる官僚層を支学ることで農民 の税負担は増大した。さざらにアーシャール税が外債の担保になった事実を考慮 するならば，それだけに，中央政府による地方社会の把握が大きな意味をるっ ていたことが理解される。

\section{V. 今後の展望}

以上述べてきたことから，中央政府による地方社会の把握は，地方行政・税 制改革と土地法改正との過程で進んだことが明らかになった。とりわけ農村社 会に打ける国有地管理の強化や，窮乏する国家財政の重要な財源であったアー シャール税の確保は, 土地法改正の過程でそれらの法的根拠が定められた。他 方, 商品作物栽培への免税措置や，外国人私有不動産処分認可法令などから， 当時のオスマン帝国が抢かれた国際環境もまた土地法改正に色濃く反映されて いることが示された。

このような結論から，伝統的作付体系を崩すことを潔しとしない旧来の地方 名士とは対照的に, 商品作物に特化した農業経営を行うことによって新たに勃 興したムスリム，非ムスリムが自らの小地片からなる耕作地に括ける権利の確 立を切実に要求したはずであるという永田の指摘が，1860年代以降のとりわけ バルカンやエーゲ海沿岸地域に関しては想定できると思われる。

本稿では紙幅の関係上触れられなかった, 国有地が負債のかたとして認めら れることなど国有地の商品化の問題, 私有地祘よびワクフ地さらには不動産物 件に対する課税措置の問題など，法制史的観点から考察すべき問題もな和残さ れている。これらの点をふまえて, 社会経済史的観点から一般農民と商品作物 
に特化した新興農民の実態，外国人の土地保有事情などの諸問題に取り組むこ とが今後の課題である。

（付記）本稿は日本オリエント学会第36回大会（1994年10月30日東京大学本郷 キャンパス）においてロ頭発表した原稿を加筆修正したものである。

\section{注}

（1）タンズィマート改革以前のアーヤーン研究については，永田雄三の諸研究（「歷 史のなかのアーヤーン一十九世紀初頭トルコ地方社会の繁栄——」社会史研究・ 7』日本エディタースクール，1986，pp. 81-162. など）を参照。オスマン社会経済 史研究動向は H. Inalc1k, "Ottoman Social and Economic History: A Review", (eds. O. Okyar \& H. İnalcık) Social and Economic History of Turkey (10711920), Ankara Hacettepe University, 1980, pp. 1-8., 近年のチフトリキ研究動 向は G. Veinstein, "On the Çiftlik Debate", (eds. Ç. Keyder \& F. Tabak) Landholding and Commercial Agriculture in the Middle East, State University of New York Press, 1991, pp. 35-53.。な㸱，1858年土地法の概要については拙稿 「オスマン帝国に和ける国有地制度」『イスラェル占領地情勢の研究』財団法人中東 調查会, 1993, pp. 90-100.

（2）Kânûnnâme-i Arâzî (以下『土地法令集』という：ヒジュラ暦1274-1278/18581861, 83p.), Başbakanlık Arşivi, pp. 1-41. Düstur l. series. vol. 1. (以下『法 令集』といら：ヒジュラ暦1274-1289/1858-1872)，Istanbul, 1873, pp. 165-199.

(3) Arâzi Kânunnâmesi (1274, L. 23) Komisyon Mahsûsunun Mazbatası (1858 年 4 月21日/1274. N. 7) は K. Serkiz, Tahşiyeli Kavanin, vol. 1, Istanbul, 1992 /23-1924/25, p. 175 . に揭載。

(4) Tanzimat I, Istanbul, 1940, xvi+1026+67p. これに関する書評は Ö. L. Barkan, "Tanzimat tetkiklerinin ortaya koyduğu bazı meseleler", İstanbul $\ddot{U}_{\text {nive- }}$ rsitesi İktisat Fakültesi Mecmuası, Vol. II, No. 2, pp. 288-329.

(5) E. Engerhardt, Türkiye ve Tanzimât, (tr. A. Reşad), Istanbul, 1910, 494p.

(6) H. İnalcık, "Tanzimat Nedir?", Dil ve Tarih-Coğrafya Fakültesi Dergisi No. 1, 1940/41, p. 238.

(7) R. H. Davison, Reform in the Ottoman Empire 1856-1876, New York, 1973 (2. ed.), xviii +483p. S. J. Shaw \& E. K. Shaw, History of the Ottoman Empire and Modern Turkey, Vol. II, Reform, Revolution, and Republic: The Rise of Modern Turkey 1808-1975, London, 1985 (3. ed.), xxv+518p. 護雅夫 「タンズィマート」『世界の歴史』第 7 巻, 筑摩書房, 1971, pp. 233-247., 「オス マン帝国の改革運動1.トルコの改革運動」『岩波講座世界歴史』第21巻，岩波書店， 
1971，pp. 386-410．永田雄三「タンズィマート」護雅夫編『トルコの社会と経済』 アジア経済研究所，1971，pp. 1-28，「トルコ; オスマン帝国の改革運動之半植民地 化」『中東現代史 I 』山川出版社，1982，pp. 70-108など。

（8）例光ば1989年，タンズィマート150周年記念論集 Tanzimat'in 150. Ylldönümü Uluslararası Sempozyumu, Ankara, 1994, T. T. K., 580p. および ed. H. D. Yildiz, 150. Yzlinda Tanzimat, Ankara, 1992, T. T. K., x+598p.なぞ。

(9) İ. Ortayl1, Tanzimattan Sonra Mahalli İdareler (1840-1878), Ankara, 1974, xiv $+280 \mathrm{p}$.

(10) M. Çadırc1, Tanzimat Döneminde Anadolu Kentleri'nin Sosyal ve Ekonomik Yapılar, Ankara, 1991, xiii+410p. な㸱, S. J. Shaw, Local Administrations in the Tanzimat, 150. Yilında Tanzimat, pp. 33-49. もある。

(11) T. Güran, Tanzimat Döneminde Osmanl Maliyesi: Bütçeler ve Hazine Hesapları (1841-1861), Ankara, 1989, 154+21p. A. Şener, Tanzimat Dönemi Osmanl Vergi Sistemi, Ankara, 1990, 278p.

（12）例光ば，拙稿「「サェル法」と現実一ボスニア・ヘルッェゴヴィナのチフトリ キに関する法令（1859年）一」『東欧史研究』16号，1993，pp. 48-75。

(13) Ö. L. Barkan, "Türk Toprak Hukuku Tarihinde Tanzimat ve 1274 (1858) Tarihli Arazi Kanunnamesi”, Tanzimat I, T.T.K., pp. 321-421.

(14) H. Cin, Mirî Arazi ve Bu Arazinin Özel Mülkiyete Dönüş̧ümü, Konya, 1987 (2. ed.), $x v i i+409 \mathrm{p}$.

(15) H. İnalc1k, op. cit., Tanzimat ve Bulgar Meselesi, Ankara, 1943, xi+161p., および “Tanzimatın uygulanması ve sosyal tepkileri”, Belleten XXVIII, 1964, pp. 623-690.

(16）このことは H. İnalc1k \& D. Quataert, eds., An Economic and Social History of the Ottoman Empire 1300-1914, Cambridge, 1994, xxxi+1026 p. の第 5 章 「アーヤーンの時代」が，1812年までを报っていることにも象徵されている。1812年 に始まるマフムト 2 世の中央集権化政策については, 永田雄三「マフムート二世の中 央集権化政策の一端—アーヤーン，デレベイ対策をめぐって一」『オリエント』 Vol. XII, Nos. 3-4, 1971, pp. 149-168.

(17) D.Quataert, "The age of reforms, 1812-1914", An Economic and Social History of the Ottoman Empire 1300-1914, pp. 855-856.

（18） 永田雄三「<報告>オスマン帝国に拈ける国家的土地所有原則の衰退一ーチフト りキ型大土地所有の発展」『歴史学研究』4月号 No. 618, 1991, 37 p.

（19）ただし，タンズィマート改革適用地域は主としてアナトリアとバルカンに限られ た。A. C. Eren, “Tanzimat”, İslâm Ansiklopedisi vol. 11, 1979, Istanbul, p. 720. A Şener, op. cit., pp. 23-24.。

(20）例总ば Y. Nagata, "Manisa Şer‘î Mahkeme Sicil Defterlerinden Bir Kaç 
Not", Osmanlı Tarihi Araştırma ve Uygulama Merkezi Dergisi (OTAM) No. 3, 1992, pp. 285-296.

（21）中央政府機構については, A. Akyıldız, Tanzimat Dönemi Osmanlı Merkez Teşkilatında Reform (1836-1856), 1993, Istanbul, 338+11p. および M. Seyitdanlıŏlu, Tanzimat Devrinde Meclis-i Vâlâa (1838-1868), 1994, Ankara, T. T. K., xiv +227p.。

（22） 1847年 4 月 23 日（1263 CA. 7) 付公文書は Takvîm-i Vekâyi 1 . series. (以 下『官報』という：1831-1874)，No. 331. 特よび K. Serkiz, op. cit., pp. 124-126. に揭載。さらに，1847年 5 月21日（1263 C. 5) 付土地法令では, 今後は土地証文に は花押付用紙が使用され，財務局の台帳に証文の内容が記載されると規定された。

Kânûn-i Kalemiye（以下『書記局法令』といら：ヒジュラ暦1256-1260/1840-1844, 57p.), Başbakanlık Arşivi, pp. 10-14.

(23) Meclis-i Tanzimât Mazbatası（1858年5月19日/1274. L. 5) は K. Serkiz, op. cit., p.176. に掲載。なお，これに類似した記述は59年土地証文法令に関する同委 員会の公文書（1859年 1 月 11 日/1275 C. 6) にも見られる（『土地法令集』p. 52.)。

（24）州議会, 県議会, 郡議会とは1840年, 州知事, 県知事, 郡長を中心にそれぞれ組 織され，徵税をはじめ地方行政府の役割を担った。詳細は I. Ortayl, op. cit. およ び M. Çadircı, op. cit.

（25）1859年 1 月11日（1275 C. 6)『法令集』pp. 200-208. および『土地法令集』pp. 42-51.

（26）財務官吏，即ち財務官（defterdâr）や財務監督官（mal müdirleri）および郡長 (kaza müdirleri) は, ティマール制下のスィパーヒーのように「土地所有者」とみ なされた。財務官の職務や不正については M. Çadirc1, op. cit., pp. 227-230.

（27）1858年 9 月 22 日（1275 S. 13）付地方州法令は『官報』No. 566-574に 掲載。

（28）保有権の移転方法には譲渡, 無償相続, 有償相続, 競売があり, 手続き内容が土 地証文の欄外に記載された。

（29）土地証文代金を支払わずに国有地における保有権を相続できる者。伝統的には息 子のみだったが1847年には息子と娘へ，58年土地法では息子と娘，父，母の順に無償 相続権が認められた。

（30）有償相続人が取得を拒絶するか，あるいは存在しない場合，土地の面積が 100 ド ニュム以下なら郡会議が，100ドニュムから500ドニュム以下なら県会議が競売を行っ た。500ドニュムより上の場合には郡・県での競売の後，国庫でも競売が実施された。 ただし，1886年 7 月13日（1303 L. 11）付法令で100ドニュムは300ドニュムに引き上 げられた（『土地法令集』p.79)。

(31) C. Issawi, The Economic History of Turkey 1800-1914, Chicago and London, 1980, pp. 202-203.

（32）『法令集』pp. 608-624. 
（33）筆者が地券地籍簿総局を訪問した1994年 8 月現在，同総局にはトルコのみならず, シリア，イスラェル，エジプト，ブルガリアその他の諸国から送られてくるオスマン 時代の土地証文と，同総局所蔵の土地台帳とを照合し，土地証文の正当性を確認する 作業を通常の業務とする部局がある。こうした事実にふれると，中東・バルカン地域 飞抒ける土地法改正の影響の重要性を改めて認識せざるを得ない。

（34）プライバシー保護のため具体的人名, 所在地等の情報は明らかにできない。

（35） 1 番から 9 番までの文言はイナルジク（1941，p．262）によって紹介されたブル ガリアの1851年付土地証文の表現より形式化されている。一方, M. Eminoğlu (Osmanlı Vesikaların Okumaya Giriş, Ankara, 1992, pp. 167-169.) が示している コンヤの1888，1906/7，1912年付土地証文は花押はもちろん，所在地，面積など諸項 目が表として印刷された用紙が用いられているが，10番から12番は花押付とはい表 ではなく文章のみで、 コンヤのそれのような「近代的」形式の用紙ではない。

（36）「A氏文書」では耕作地の「売却」の際，土地証文税が支払われ，また「土地は 国有地だから」（4番）といら記述も見られることなどから，法的には寲似ワクフ （gayr-i sahîh vakıflar）地，すなわち58年土地法に捺いては国有地とみなされた土 地を対象にしているといえる。58年土地法第 4 条によれば，国有地の中からより分将 られて，スルタン自身が，あるいはスルタンの許可で他の者たちがワクフ設定した土 地は真性ワクフ（evkâf-1 sahîh）地ではないと規定され，さらにオスマン帝国に存 在するワクフ地の大部分はこの種のワクフ地であると述べられている。「真性ワクフ 地」「疑似ワクフ地」の詳細は Ö. L. Barkan, “Milli Topraklar ve Sultanlarin Temlik Hakkı (1)", İstanbul Üniversitesi Hukuk Fak. Mecmuası vol. VII, 1941, pp. 157-176.。もちろ几当事者たちは，「売却」された国有地を自らの所有地ととら えていたであろらが，いずれにせよこれらの土地証文が保有権の正当なる証として個 人に授与され，さらにその子孫が100年以上にわたって保管していたのであった。

（37）例㓪ば，ボスニアで州の高官とは地方名士の抜きんでた指導者を意味するとジェ ヴデト・パシャは述べている (ed. C. Baysun, Cevdet Paşa: Tezâkir, No. 21-39, T. T. K., 1986, p. 29.)。

（38） ed. C. Baysun, op. cit., No. 21, pp. 3-19. この一部については拙稿「サフェ ル法と現実」で紹介。

（39）『法令集』pp. 230-331. な特，外国人私有不動産処分認可法令については拙稿「才 スマン帝国に战汗る国家的土地所有原則の形骸化之法的存続」『現代中東研究』(印刷 中）を参照。

(40) C. Issawi, op. cit., pp. 205.

(41) O. Kurmuş, Emperyalizmin Türkiye'ye Girişi, Ankara, 1982 (3rd. ed.), p. 79.

(42) 詳細は H. İnalc1k 1964.

（43） 1840年 4 月18日（1256 S. 15）付Ilmühaber，『書記局法令』pp. 1-5.な打本公 
文書は R. Kaynar, Mustafa Reşit Paşa ve Tanzimat, T. T. K., Ankara, 1985, pp. 258-263. に全文が, Ö. L. Barkan 1940, pp. 354-356. でも一部が紹介されて いる。

（44）伝統的諸税の廃止については Birinci Köy ve Ziraat Kalkınma Kongresi, Türk Ziraat Tarihine Bir Bakış, Istanbul, 1938, pp. 65-68. A. Şener 1990, pp. 94-96, 119-121.。な技, Ö. L. Barkan (1940, pp. 357-358) は複雑な税体系に おかれていたためアーシャール税の統一が混乱をもたらしたであろらと述べている。

（45）また，家畜に関する税は羊税 (ağnam resmi) 和よび家畜税 (canavar resmi) として簡略化された。

（46）資産税の前身は1826年に導入された計量税。資産税は1839年から58年までは一括 して (ancemâatın) 村ごとに税額が配分され，59年から個人単位に課せられる“temettü, vergisi”となった。 (Temettuat Defteri Kataloğu, vol. 1, 1988, Başbakanlık Arşivi)。なお，A. Şener (1990， p. 99 および 1992， p. 261) によれば, “ancemâatın” 税は 59/60 年から地方によって段階的に廃止されたが, “temettü“ vergisi” に切り替わらなかった地域もあったといら。ただし，伝統的諸税の廃止拉 よび資産税統一に関する構想と試みはマフムト 2 世時代に開始されたことを忘れては ならない。例えば, 資産税算出のための検地はブルサとガリポリをモデル地域として 着手された。1838年 8 月 7 日（1254 CA. 16）付 ferman『官報』No. 169.なお， これについては Shaw 1985, pp. 40-41., A. Şener 1990, pp. 94-95. も参照。

(47) Başbakanlık Osmanlı Arşivi Rehberi, Ankara, 1992, p. 281.

(48) A. Şener 1990, p. 109. タンズィマート改革期末期にギリシア人，モンテネグロ 人，七ルビア人，イラン人には資産税の支払が義務づけられたといら。

(49) Milli Tetebbular Mecmuası, vol. 1. Istanbul, ヒジュラ暦1331-32/1912-14, p. 50-51. ハラージュ地に課せられる税は二種あり, 一方は割当のハラージュ（harâc-1

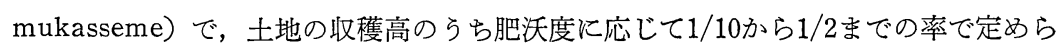
れた税である。他方はハラージュ (harâc-1 muvazzzaf) と呼ばれ, 土地に応じて定 められた一定額の税である(58年土地法第 2 条)。

(50) Ö. L. Barkan, XV ve XVI ıncı Asırlarda Osmanlı Imparatorluğunda Zirâ̂

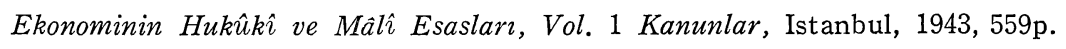
（51）ただし，アーシャール税の徵収に拈いても，単純に競売にふされるのではなく， 徵税請負が復活した1842/43 (A. Şener 1990, pp. 132-133.では43/44) 年度は, 過去 3 年間の収穫料の平均值をとった 2 年間の徵税請負が， $47 / 48$ 年度からは，請負額の 值上げ幅を確定した 5 年間の徵税請負が行われるなど，中央政府による一定の制限が 示されている (T. Güran, op. cit., pp. 14-15)。とはいえ, 最終的には地方会議に よる競売で希望者に委託される方法が56年から採用されたため, 徵税請負権の重層的 転売によって農民の負担は増加したと考えられる。

（52）1857年 8 月24日（1274 M. 3）付 irâde, 『書記局法令』 p. 48. Ö. L. Barkan 
(1940，p. 365) はこれまで，登録が明確になされてこなかった夏営地特よび冬営地を 国有地として取り扱らことによって，国有地適用範囲を法的に拡大したと述べている。 （53）国有地上の私有の果樹，樹木，チフトリキの製粉場 (deǧirmen), 羊囲い(ağ11) 脱款場 (harman yeri) などに対して課せられたタプ税（resm-i tapu）㐫るいは家 屋のタプ (dam tapusu) に相当する税。

(54) Birinci Köy ve Ziraat Kalkınma Kongresi, op. cit., p. 128, 138.

（55）このような観点からの考察は Ö. L. Barkan 1940, pp. 393-411.

(56) D. Quataert, op. cit., p. 857.

(57）スルタンの勅令には日付がないが，最高司法審議会議のものとみられるスルタン への上奏文は1867年 9 月 10 日（1284 CA. 11）付 (『土地法令集』p. 62-64.)。

（58）このような租税徵収方法は，所有権付与の代償に 6 年分の税金の前払を命じたエ ジプトのムカーバラ法（1871年）の措置に類似している（加藤博『私的土地所有権の 確立と近代エジプト社会』，1993，創文社，pp. 21-22.)。ただし，オスマン帝国では 国有地に和ける保有権拡大がすすんでも，所有権（ラカバ）はあくまでも国家に帰属 し続けた。

（59）土地法第121条には「私有認可証（mülkname-i hümâyûn）」が合法的私有地の 証になって扣り，59年土地証文法令第15条に执いても「私有認可証」で保有されたチ フトリキは「私有認可証」の記載条件に従らと規定された。もらろん，67年の勅令に おいても,「私有認可証」付私有地に課される一年毎の税については今後の特別な決 定に従うとただし書きされているが，いずれにせよ，同勅令は「私有認可証」付私有 地と国有地とに拈ける課税措置が接近する過程を表していると思われる。

(60) T. Güran, op. cit. pp. 64-65. A. Şener 1990, p. 220.

(61) A. Şener 1992, p. 268.

（62）土地証文税，すなわちタプ（tapu）税とは「保有権の代償として支払われる代金 （mu“accele）であり，国家官吏によって徵収され，国庫に収められる（58年土地法第 3 条)」ものである。これは国有地の保有権を示す土地証文を取得する際支払う税で, 理論上は国有地が農民に貸し与えられる時の前金と見なされ，事実上は国有地の売却 代金と考光られる。

（63）用紙代，相続税，譲渡税については59年および47年土地証文法令（1847年 5 月 21

日/1263 C. 5)『書記局法令』p. 11,『官報』No. 331 .

(64) A. Şener 1990, p. 220.

(65) D. Quataert, "Main Problems of the Economy during the Tanzimat

Period", 150. Yilında Tanzimat, Ankara, 1992, T. T. K., p. 215.

(66) 永田雄三 1991, p. 40 . 